\title{
Field trips as short-term experiential learning activities in legal education
}

\author{
Noelle Higgins $^{\mathrm{a} *}$, Elaine Dewhurst ${ }^{\mathrm{a}}$ and Los Watkins ${ }^{\mathrm{b}}$ \\ ${ }^{a}$ School of Law and Government, Dublin City University, Glasnevin, Dublin, Ireland; \\ ${ }^{b}$ School of Law, University of Hertfordshire, UK
}

\begin{abstract}
Field trips offer students the opportunity to learn in a real-world setting and bridge the gap between theory and practice. To date, there has been a dearth of both theoretical and empirical research into the use and effectiveness of field trips as a pedagogic tool in legal education. This article seeks to fill this gap, first by analysing the current research on the use of field trips in higher education across different disciplines and the reported advantages and disadvantages of such usage, and secondly by providing empirical evidence on the benefits of such activities from a field trip, "Living the Law: A Tour of Legal Dublin", undertaken with students in Dublin City University, Ireland. The tour involved visits to important legal establishments in the city of Dublin, including the Supreme Court, the training institutions of barristers and solicitors in Ireland and a premier legal firm. The article analyses feedback from the students who took this trip on the benefits of such a learning experience.
\end{abstract}

\section{Introduction}

Law school provides the single experience that virtually all legal professionals share. It is the place and time where expert knowledge and judgment are communicated from advanced practitioner to beginner. It is where the profession puts its defining values and exemplars on display, and future practitioners can begin both to assume and critically examine their future identities. ${ }^{1}$

In 1881, Justice Oliver Wendell Holmes wrote that "[t]he life of the law has not been logic; it has been experience". ${ }^{2}$ Yet despite this early emphasis on the importance of experiential learning in legal education, law schools continue to be criticised for "lack of attention to practice and inadequate concern with professional responsibility", 3 and continue to be heavily reliant on "a single,

\footnotetext{
*Corresponding author. Email: noelle.higgins@dcu.ie

${ }^{1}$ William M. Sullivan, Anne Colby, Judith Welch Wegner, Lloyd Bond and Lee S. Schulman, Educating Lawyers: Preparation for the Profession of Law (San Fransisco: Jossey-Bass, 2007) p. 3.

${ }^{2}$ Oliver Wendall Holmes, The Common Law (Little Brown \& Co., 1881) p. 1.

${ }^{3}$ Educating Lawyers, supra n. 1 at p. 6.
} 
heavily academic pedagogy". ${ }^{4}$ Law schools are under ever-increasing pressure, both from within the legal profession and from outside influences, including law firms, to provide some form of interaction with the real world, in order to develop knowledge, expand skill sets and transform attitudes and values. This article explores, through the use of empirical evidence, whether field trips, as a type of short-term experiential education, can be a unique and constructive means of uniting "the two sides of legal knowledge: formal knowledge and experience of practice". ${ }^{5}$

Many schools of law will encourage students to visit local courts; indeed, many will organise such a visit, and certainly in the UK, there is a growing culture recognising scholarly engagement with the community, particularly with a community of practice. ${ }^{6}$ In addition, there are well-established programmes in many law schools whereby students can undertake internships, pro bono work or summer schools, but these differ in intent and content from the present study.

This particular field trip was, therefore, undertaken as a short-term, intensive, organised trip to specified legal institutions in Dublin, with a view to allowing law students to take a step into the "zone of proximal development" ${ }^{\text {"7 }}$ of various possible employment futures. There may be a consideration that this approach ${ }^{8}$ is only possible near a large legal conurbation, but the authors suggest that it would be replicable almost anywhere, by the inclusion of various courts, barristers/solicitors, police, prisons, or, indeed, any other arm of the legal or politico-legal institutions within a reasonable radius of the particular law school.

To date, there has been a dearth of both theoretical and empirical research into the use and effectiveness of field trips as a pedagogic tool in legal education. This article seeks to fill this gap, first by analysing the current research on the use of field trips in higher education across different disciplines and the reported advantages and disadvantages of such usage, and secondly by providing empirical evidence ${ }^{9}$ on the benefits of such activities from a field trip, "Living the Law Tour", undertaken with students in Dublin City University, Ireland.

"Living the Law Tour" was undertaken by 20 law students at Dublin City University as part of their first year law class. This tour was intentionally placed

\footnotetext{
${ }^{4}$ Educating Lawyers, supra n. 1 at p. 6.

${ }^{5}$ Educating Lawyers, supra n. 1 at p. 8.

${ }^{6} \mathrm{~J}$. Lave and E. Wenger, Situated Learning (Cambridge: Cambridge University Press, 1991).

${ }^{7}$ L.S. Vygotsky, Mind in Society (Cambridge, MA: Harvard University Press, 1978) at p. 86.

${ }^{8} \mathrm{~A}$ similar tour is undertaken annually in London by the Law School of the University of Hertfordshire by senior lecturers Klearchos Kyriakides, Ralph Camp and Los Watkins, which requires a round trip of some 40 miles. The authors would like to thank Dr Kyriakides for sharing his ideas on field trips.

${ }^{9}$ Mary C. Wright, "Getting More out of Less: The Benefits of Short-Term Experiential Learning in Undergraduate Sociology Courses" (2000) 28(2) Teaching Sociology 116, 121. See also Rik Scarce, "Field Trips as Short-Term Experiential Education" (1997) 25 Teaching Sociology 219, 219.
} 
within the "Foundations of Law and Legal Research" module as this module introduces the students to the fundamental skills and concepts that are required for a successful legal career. Students participated in pre- and posttour reflection seminars and were asked to participate in a survey to provide feedback on the experience for research purposes. The surveys analysed the general learning outcomes of the field trip, as well as the skills and changes in attitude that the field trip engendered. These results are analysed in this article and provide empirical evidence on the benefits of field trips in the law curriculum.

\section{Current research on the use of field trips in higher education}

Field trips have been categorised as a form of short-term experiential education. ${ }^{10}$ Experiential education can be defined as "education (the leading of students through a process of learning) that makes conscious application of the students' experiences by integrating them into the curriculum"11 and ensures that the "learner is directly in touch with the realities being studied". ${ }^{12}$ Experiential education has been described as having a number of essential characteristics: (1) it "is best conceived of as a process, not in terms of outcomes"; ${ }^{13}$ (2) it "is a continuous process grounded in experience"; ${ }^{\prime 14}$ (3) it requires the "resolution of conflicts between dialectically opposed modes of adaptation to the world"; ${ }^{15}$ (4) it is a "holistic process of adaptation to the world"; ${ }^{16}$ (5) it involves "transactions between the person and the environment"; $;{ }^{17}$ and (6) it is a "process of creating knowledge". ${ }^{18}$

\section{Defining field trips}

Short-term experiential education requires "students to integrate course material with a brief excursion to observe or participate in a related social

\footnotetext{
${ }^{10}$ Scarce, supra n. 9 at p. 219.

${ }^{11}$ Rebecca Carver, "Theory for Practice: A Framework for Thinking about Experiential Education" (2008) 3 Philosophical Foundations 149, 150.

12 Morris T. Keeton and Pamela J. Tate, "Editors' Notes: The Boom in Experiential Learning" in Morris T. Keeton and Pamela J. Tate (eds), Learning by Experience: What, Why and How (San Fransisco: Jossey-Bass, 1978) p. 2. See also Cantor who defines experiential education as "learning activities that engage the learner directly in the phenomena being studied": Jeffrey A. Cantor, Experiential Learning in Higher Education: Linking Classroom and Community (ERIC Clearinghouse on Higher Education, 1997) 1. Cf. Wright supra n. 9 at p. 116.

${ }^{13}$ David A. Kolb, Experiential Learning: Experience as a Source of Learning and Development (Upper Saddle River, NJ: Prentice Hall, 1984) 26. Jerome Bruner, Toward a Theory of Instruction (Cambridge, MA: Belknap Press, 1966) at p. 72 has advocated the "[k]nowing is a process, not a product" theory, i.e. the idea that the purpose of education is not to memorise information but to gain the skills necessary to acquire knowledge.

${ }^{14}$ Kolb, supra n. 13 at p. 27.

${ }^{15}$ Kolb, supra n. 13 at p. 29.

${ }^{16}$ Kolb, supra n. 13 at p. 31

${ }^{17}$ Kolb, supra n. 13 at p. 34.

${ }^{18} \mathrm{Kolb}$, supra n. 13 at p. 36.
} 
phenomenon". ${ }^{19}$ Beirsdorfer and Davis define a field trip as "part of a day, a day long, or a weekend long excursion; it can be a simple guided tour to an area of interest, or it may include the conducting of an active research oriented (inquiry type) field project". ${ }^{20}$ Such activities are particularly suitable to primary and secondary education, particularly in science subjects ${ }^{21}$ and have also proved useful, although are by no means limited to, ${ }^{22}$ the teaching of social and natural science disciplines at a tertiary level. ${ }^{23}$ The study of law as a living discipline, which requires law students to interact with institutions, legal professionals, colleagues and judges, is well suited to the use of field trips as a means of contextualising acquired academic legal knowledge. However in law, as in other areas of higher education, field trips are certainly an underused pedagogical technique ${ }^{24}$ despite the fact that if such trips are "conceived with imagination and planned with attention to detail, [they] can be among the most intensive, in-depth, integrative, and rewarding of educational experiences for students and instructors alike". ${ }^{25}$

\section{The advantages of field trips: reflections from other disciplines}

A review of current literature on field trips from other disciplines (e.g. the social and natural sciences) reveals a myriad of advantages to be gained from such activities. Field trips can have substantive benefits for undergraduate students in assisting them to make important connections between the theoretical knowledge learned in the lecture theatre and real life, "at a depth that cannot be gained through books and lectures alone" 26 and aids in the understanding of abstract concepts. ${ }^{27}$ Students are encouraged to think critically and creatively ${ }^{28}$ beyond the parameters of the classroom environment, ${ }^{29}$ to challenge their preconceived notions and stereotype $\mathrm{s}^{30}$ and to actively engage with the theoretical knowledge that they have mastered. There is also an

\footnotetext{
${ }^{19}$ Wright supra n. 9 at p. 116. Cf. Scarce, supra n. 9.

${ }^{20}$ Raymond E. Beirsdorfer and William E. Davis, "Suggestions for Planning a Class Field Trip" (1994) 24 Journal of College Science Teaching 307 quoted in Avi Hofstein and Sherman Rosenfeld, "Bridging the Gap Between Formal and Informal Science Learning" (1996) 28 Studies in Science Education 87, 94.

${ }^{21} \mathrm{Cf}$. Hofstein and Rosenfeld, supra n. 20.

${ }^{22}$ Michael F. Follo, "Field Trips as a Teaching Method" in Keith W. Prichard and Robert McLaran Sawyer (eds), Handbook of College Teaching: Theory and Applications (Westport, CT: Greenwood Publishing Group, 1994) p. 189.

${ }^{23} \mathrm{Cf}$. Scarce, supra n. 9.

${ }^{24}$ Scarce, supra n. 9 at p. 220 . Wright comments that only a minority of professors adopt experiential learning techniques in their classrooms - Wright supra n. 9 at p. 116.

${ }^{25}$ Scarce, supra n. 9 at p. 226.

${ }^{26}$ Wright, supra n. 9 at p. 117

${ }^{27}$ Wright, supra n. 9 at p. 122.

${ }^{28}$ Scarce, supra n. 9 at p. 220.

${ }^{29}$ Catherine E. Boyle, "Seeing Gender in Everyday Life: A Field Trip to the Mall" (1995) 25 Teaching Sociology 150, 153.

${ }^{30}$ Scarce, supra n. 9 at p. 220.
} 
important novelty factor which can enhance student engagement and participation in their academic lives as the "novel, clearly discriminable events are remembered quite easily". ${ }^{31}$

From a pedagogical perspective, students can benefit considerably from the active learning environment of the field trip, as it alters the classroom climate, the learning processes and can impact on the enthusiasm of the lecturers for the particular subject. ${ }^{32}$ Students and lecturers that have undertaken field trips together often reflect on the experience as one that brought faculty members and students closer together, thus creating a more supportive learning environment. ${ }^{33}$ Field trips engage "and even entertain students, helping to make the educational experience more enjoyable and ... more memorable and more sociologically meaningful", ${ }^{34}$ increasing the motivation of the students for their subject matter. ${ }^{35}$

However, one of the most significant benefits of field trips is the transitional impact on students. Field trips, particularly those aimed at the application of theoretical knowledge in a professional environment, can facilitate very effectively "the transition between undergraduate education and the workforce, subsequent courses in the discipline and post-baccalaureate schooling", ${ }^{36}$ as well as exposing undergraduates to potential employment opportunities, ${ }^{37}$ developing their social skills ${ }^{38}$ and defining their professional goals. ${ }^{39}$ Often, students are uncomfortable or too intimidated ${ }^{40}$ to engage with the professions prior to completing their undergraduate education and field trips of this nature can allow students to connect with professionals and to access locations to which they may not normally be admitted entry. ${ }^{41}$

\section{The disadvantages of field trips: reflections from other disciplines}

The main disadvantages of field trips identified in the literature arise from the methodological and logistical issues concerning the preparation, performance and follow-up to the field trip. The "administrative road blocks" 42 of

\footnotetext{
${ }^{31}$ John Falk and John Balling, "The Field Trip Milieu: Learning and Behaviour as a Function of Contextual Events" (1982) 76(1) The Journal of Educational Research 22, 23.

${ }^{32}$ Wright, supra n. 9 at pp. 117 and 122.

${ }^{33}$ Scarce, supra n. 9 at p. 224.

${ }^{34}$ Scarce, supra n. 9 at p. 220.

${ }^{35}$ Scarce, supra n. 9 at p. 220.

${ }^{36}$ Wright, supra n. 9 at pp. 117-118.

${ }^{37}$ See the research of Arthur W. Chickering, Experience and Learning: An Introduction to Experiential Learning (New Rochelle, NY: Change Magazine Press, 1977) and Joseph K. Rippetoe, "The Undergraduate Education in Sociology: A Case for Experiential Learning" (1977) 4 Teaching Sociology 239 and Wright, supra n. 9 at p. 118.

${ }^{38}$ Cantor, supra n. 12 and Wright, supra n. 9 at p. 118.

${ }^{39}$ Jane S. Gore and Helen Y. Nelson, "How Experiential Education Relates to College Goals and Objectives" (1984) 7 Evaluation and Programme Planning 143 and Wright, supra n. 9 at p. 118.

${ }^{40}$ Scarce, supra n. 9 at p. 224.

${ }^{41}$ Scarce, supra n. 9 at p. 224.

${ }^{42}$ Scarce, supra n. 9 at pp. 224-225.
} 
the logistics, transport, insurance, ethics, access to the field trip site, cost, lack of support from the school administration ${ }^{43}$ and time burdens on both the students and the instructors ${ }^{44}$ are the most common concerns facing those engaged in field trip development. ${ }^{45}$

A possible additional concern is preventing what has become known as the "zoo phenomenon", ${ }^{46}$ described by Grant et al. This arises in circumstances where the field trip is not properly synthesised with the educational curriculum (e.g. failure to prepare or focus the students adequately) and students cannot actively engage with the learning experience. ${ }^{47}$ In such circumstances academics have little control over what is learned or over student behaviour. ${ }^{48}$ There are a number of important methods by which this "zoo phenomenon" can be avoided. Meticulous planning and development of the field trip are essential and a key element is the preparation in advance of the field trip. Pre-field trip preparation, finding a suitable time in the curriculum in which to conduct the field trip, preparation of materials in advance, scrupulous planning of the logistics on the day and post-field trip discussions are all effective ways of alleviating this problem. ${ }^{49}$

\section{Current research on the use of field trips in legal education}

"Society cannot be studied apart from experiences in society"50 and law, as a reflection of the norms of society, cannot be studied separately from this interaction with the subjects, enforcers and creators of the law. Law schools currently regularly employ a wide range of pedagogical techniques and strategies which facilitate experiential learning, such as clinical programmes, moot courts and other simulation activities. ${ }^{51} \mathrm{~A}$ common thread of the recommendations of The Carnegie Foundation for the Advancement of Teaching ${ }^{52}$ report

\footnotetext{
${ }^{43}$ David Anderson and Zuochen Zhang, "Teacher Perceptions of Field-Trip Planning and Implementation" (2003) VI(III) Visitor Studies Today 6.

${ }^{44}$ The time involved for instructors can be immense and includes preparation of both the trip logistics and the materials, the field trip itself and the post-field trip feedback sessions. See Anderson and Zhang, supra n. 43 at p. 6.

${ }^{45}$ See Corey Muse, Leigh Chiarelott and Leonard Davidman, "Teachers' Utilization of Field Trips: Prospects and Problems" (1982) 56(3) The Clearing House 122 for more information on the common challenges associated with field trips.

${ }^{46}$ Linda Grant, Max Heirich, Steven S. Martin and Ellen Van Eck, "The Detroit Tour: Experiential Learning within the Framework of a Large Lecture Course" (1981) 9(1) Teaching Sociology 15, 23 and Wright, supra n. 9 at p. 118.

${ }^{47}$ Grant et al., supra n. 46 and Wright, supra n. 9 at p. 118.

${ }^{48}$ Muse et al., supra n. 45 at p. 123.

${ }^{49}$ Muse et al., supra n. 45 at p. 125.

${ }^{50}$ Scarce, supra n. 9 at p. 223.

${ }^{51}$ David M. Siegel, "The Ambivalent Role of Experiential Learning in American Legal Education and the Problem of Legal Culture" (2009) 10 German Law Journal 815, 815.

${ }^{52}$ Educating Lawyers, supra $\mathrm{n}$. 1: Summary of the Findings and Recommendation, available at http:// www.carnegiefoundation.org/sites/default/files/publications/elibrary_pdf_632.pdf. (accessed 22 April 2012).
} 
on legal education addresses the importance of "integrating the experiential or practical aspects of legal education with doctrinal ones". ${ }^{53}$

To date, there has been a lack of research conducted on the impact of field trips in legal education, despite the fact that many law faculties include field trips as part of the educational experience. Visits to courts, prisons and other legal institutions are the most common types of field trips included in the law school curriculum but these seem to be conducted on an ad hoc basis outside the official curriculum with little or no research to support the efficacy or otherwise of the field trip.

In the United States, law faculties appear to incorporate field trips more centrally into the curriculum than law faculties in other jurisdictions, offering students the opportunity to visit penitentiaries, ${ }^{54}$ court houses $^{55}$ and law firms. ${ }^{56}$ In Ireland and in the United Kingdom, a brief survey of institutions reveals that law faculties occasionally cater for field trips to local courts or to prisons and some even to the European institutions such as the European Parliament and Court of Justice of the European Union. ${ }^{57}$

\section{The "Living the Law Tour": a tour of legal Dublin}

On 3 March 2011, Dublin City University, School of Law and Government in cooperation with the Socio-Legal Research Centre organised and delivered the inaugural "Living the Law Tour" for 20 (10 male/10 female) first year undergraduate law students. The students were taken on this tour as part of their first year module, "Foundations of Law and Legal Research" and were chosen to participate on the basis of their results in their first semester examinations.

The students met with the members of staff who organised the tour a week before the event to discuss the purpose of the field trip, the logistics and what they should be looking out for on the tour. Any questions that the students had about the tour were also addressed at this point. Students were encouraged to participate fully in the activities of the day and to engage with the individual aspects of the tour. Students were given a "Living the Law Tour Pack" which contained detailed information on the format of the tour, the institutions that they would be visiting and the persons with whom they would be engaging.

\footnotetext{
${ }^{53}$ Siegel, supra n. 51 at p. 816.

${ }^{54}$ See for example University of Pennsylvania Law School, Criminal Law Theory Class who take a trip to the Eastern State Penitentiary available at http://www.law.upenn.edu/cf/registrar/descriptions/ alphabetical.cfm (accessed 22 April 2012).

${ }^{55}$ See for example Yale Law School, Small Group Field Trip to the Second Circuit Court of Appeals in New York available at http://www.law.yale.edu/admissions/6047.htm (accessed 22 April 2012).

${ }^{56}$ See for example University of Wisconsin "Professor Heymann's Field Trip to the Real World" available at http://hosted.law.wisc.edu/batlaw/fieldtrip.html (accessed 22 April 2012).

${ }^{57}$ For example, University College Cork/University College Dublin/NUI, Galway also conduct tours of the European Union Legal Institutions. Dublin City University conduct a Legal Tour of Dublin.
} 
The tour began at 9.30am at the Law Society of Ireland, the professional training body of solicitors in Ireland. The students met in a group and were given a short introduction to the Law Society of Ireland. The students were then taken to the main lecture theatre where they attended a lecture that was being delivered to trainee solicitors on the subject of criminal litigation. The lecture was delivered in an unusual style with four criminal law expert solicitors taking questions from the trainee solicitors and answering them in a very practical way. The lecture tied in with subject matter that the students were learning in their criminal law theory class in Dublin City University (DCU). After the lecture the students were taken on a tour of the law school, the lecture theatres, the tutorial and advocacy rooms, the library and the IT rooms. The students were then gathered together for a careers seminar delivered by the Careers Officer in the Law Society on how to become a solicitor, the programme of study and the career options available after the course. The students were very interested in the practical elements of becoming a solicitor including the examination requirements, the costs and the potential for travel after the course was completed and all of their questions were welcomed and answered.

After the Law Society of Ireland, the tour progressed to the Four Courts to see the High Court and the Supreme Court in action. Students had a short tour of the historic buildings followed by a visit to the Supreme Court where they sat in on a bail hearing. Students observed the layout of the courtroom, the persons involved in the court proceedings, the advocacy of the barristers and the interaction of the Supreme Court judges with the legal teams. Students also got an insight into the more informal side of the judicial system by watching barristers negotiate on behalf of their clients in the corridors and outside the courtrooms.

The introduction to the courtroom and the role of the barrister was a very good prelude to the next stop on the tour - the King's Inns, which is the professional training school for barristers in Ireland. Once again students were given a tour of the celebrated building where the trainee barristers study and were given a very enlightening and entertaining tour by the Under Treasurer of the Inns in which she described in colourful detail the life of a trainee barrister in the Inns, the customs and practices of trainee barristers and what the Inns expected from its students. The Dean of the School of Law also then took the students to a lecture theatre to explain the very practical requirements of becoming a barrister, including examination requirements and the cost.

The final stop on the tour was a reception at A\&L Goodbody solicitors, one of Ireland's premier and largest corporate law firms. The students were treated to a very warm reception by the firm, were given a tour of the offices and had an information session facilitated by the trainee recruitment section. Solicitors at various stages of their career in the firm spoke to the students about their training and areas of work. The session also focused on the essential characteristics of a trainee solicitor, the importance of participation in extra-curricular activities in university, and the preparation of an impressive curriculum vitae. The students were then presented with much anticipated food and were given 
the unique opportunity to speak with these solicitors in a very relaxed and informal setting.

After a long and tiring day for both students and lecturers, the tour dispersed but met the following week for a feedback session. Students were also asked to complete a post-field trip survey. The feedback session and the survey gave the students the opportunity to really consider the benefits of the trip, the impact on their legal education and their career plans. It was hoped that the survey would uncover the attitude changes engendered in the students by the field trip and ascertain an insight into the benefits of field trips as part of the law curriculum.

\section{Field trips in legal education: the empirical evidence}

While this was a time-consuming and logistically difficult event to organise, it was hoped that the empirical evidence would reveal that the educational benefits would outweigh any of the challenges that were encountered. However, the experience of the students was overwhelmingly positive and the surveys reveal a number of very interesting responses, which are set out below along with the survey questions.

\section{Did you enjoy the Living the Law Tour? Why?}

All of the students stated that they enjoyed the field trip and various reasons were provided for this enjoyment. The most common reason was the impact on their career options and direction for the future. Students were grateful to receive information on how the professional education systems and the professional bodies work. Students also indicated that the field trip had given them the "motivation to enter the legal profession". Contextualisation of the "primarily conceptual content of the lectures" was also indicated as a very important feature of the tour. Development of student and lecturer bonds was also recognised by the students as a positive outcome of the tour. One student commented:

Yes I really enjoyed the tour, it was a great day!! I learned loads about the profession, satisfied any queries I had in regards to future study in Law, sat in on a court case (the Supreme Court might I add, very cool!) and even got to visit a top law firm. Also, academics aside, it was a really good way to bond with students and lecturers! In particular, I've noticed that our course is very clique-y as it were, so it was nice to get to know students that I wouldn't normally talk to. Also, I've found it quite difficult to approach lecturers since the beginning of the year but this was a really good chance just to talk to them and I realised how approachable they are! Overall I found the tour extremely beneficial. ${ }^{58}$ [R4]

${ }^{58}$ See Scarce, supra n. 9 at p. 224 who comments on the benefits of field trips for the development of the relationships between students and academics. 


\section{What did you learn about the professions?}

In relation to the impact that the field trip had on informing the students about the professional options available to them post-graduation, ${ }^{59}$ the students once again found the field trip to be very informative in providing information as to how the professional education systems work, the practicalities of training to be a solicitor or a barrister and the realities of life as a legal professional. In particular, students also learned about the importance of developing their curriculum vitae while in university, the importance of team work and the effect that this had on their undergraduate studies. Students commented:

$[T]$ he necessary training and education for both professions is quite different ... which gave me a sense of the work that needed to be applied during my time in DCU. [R16]

I found that the relevant content of your CV extend beyond mere academic achievements (though they of course cannot be ignored). [R13]

\section{What did you learn about private practice?}

Interestingly, students once again tended to focus on the practicalities of private practice including the hours of the work, the variety of work that would be undertaken, the team work involved, the opportunities that are available for students, the demanding nature of the work and, in the case of A\&L Goodbody, the very impressive office environment that they may be able to work in. Students commented:

It is demanding work and requires a lot of effort and training. I also learned about the kind of areas large firms can specialise in. [R2]

It's more of a team environment as opposed to working as a barrister which is very much independent. [R11]

\section{What did you learn from your visit to the Four Courts?}

Students benefited greatly from the trip to the Four Courts, in particular, watching the Supreme Court case. From simply viewing the court structure students learned about the roles and functions of the legal professionals, the formality attached to the court process and even learned some procedural rules relating to the appeals function of the Supreme Court. From a legal skills perspective, $78 \%$ of students stated that they had learned a lot about legal advocacy, what

\footnotetext{
${ }^{59}$ See Wright, supra n. 9 at pp. 117-118; Chickering, supra n. 37; Rippetoe, supra n. 37 and Gore and Nelson, supra n. 39 who all comment on the benefits of field trips for the transition of the student from education to the professional world.
} 
makes a good advocate and the importance of interaction with the judges (even if this interaction was negatively perceived). ${ }^{60}$ Of great importance from an educational perspective was that students also did not find the courtroom as intimidating as they first envisaged and this inspired confidence in them. One student commented:

I learned what it was like to see the Supreme Court in action. It was particularly interesting to see the interaction between the judges and the barristers. Also I learned the placement of the various figures in the courtroom. [R17]

\section{How did the tour fit in with your programme of study?}

All the students responded that this tour was a perfect fit with their undergraduate degree programme and highlighted a variety of benefits of the tour to their undergraduate study including contextualising their academic work, motivating them to work harder, assisting them with career choices and offering them a much needed "break from the rigorous programme of study". One student commented:

It was much more practical than the most of the coursework. It was a chance to see law in action and was invaluable by comparison to anything learned in an hour's lecture. [R6]

\section{Has it changed your thoughts on what career you may pursue at the end of your degree?}

This was one of the most interesting results as it revealed that while there were some very distinct changes in attitude on the part of some students, $67 \%$ of students found that the field trip did not alter their career choice. Of those $67 \%$, however, some did note that the field trip had introduced some uncertainties but overall they were sure that they were making the right choice for them. Thirty-three per cent of students found that the field trip had radically altered their career selection, in many cases from solicitor to barrister and vice versa. Students commented:

Not particularly, I have wanted to become a solicitor for some time now. I was much more determined and motivated after the trip however! [R1]

Yes, I had originally thought about King's Inns but after listening to the trainees at A\&L Goodbody, I think I would enjoy working in a firm. [R17]

${ }^{60}$ One student was not impressed by the "apathetic nature of the Higher Court's Justices". 


\section{Would you feel more confident in engaging with these institutions in the future?}

One of the objectives of the field trip had been to develop student confidence in engaging with the professional institutions and in visiting court. After the tour $100 \%$ of students expressed an increase in confidence in dealing with the legal profession and in attending court hearings. Students expressed concerns that they had prior to the field trip and commented on the importance of the field trip in de-mystifying the professions and the courtroom. Simply "knowing the layout of a building or what to expect in a law society lecture" was of immense benefit to the students. One student commented:

Yes, I considered visiting the Four Courts before but I backed out as I did not want to enter the wrong courtroom or some other silly mistake! I now feel more confident about going again. [R12]

\section{Do you feel that this should be offered to first year students in the future?}

One hundred per cent of students were confident that this should be offered again to first year students and that the students would obtain similar benefits as they had. Students recognised the motivation that the field trip had produced in their colleagues and how it had inspired them to work harder. One student commented:

Yes, most definitely! I think it will really encourage the students to work harder and focus on their goals. [R6]

\section{Would you like to see similar activities on your BCL programme?}

The use of field trips as a form of short-term experiential education in the undergraduate law programme is only one of a number of educational initiatives that could be developed within a law school curriculum to make the study of law more practical and "real". However, the time constraint on students has to be considered, particularly where there are professional requirements as to what students must study in law school. However, $100 \%$ of students were of the opinion that short-term experiential learning techniques should be integrated more into the law school curriculum and considered that it would be "an interesting twist on the course". The impact of the field trip in contextualising the academic material learned by the students was recognised as a very positive addition to the course. One student commented: 


\section{Do you have any ideas of any activities you would like to undertake on the $B C L$ programme?}

A variety of responses was obtained from this question. Students appeared to recognise the educational benefit of the field trip and therefore proposed more field trip learning opportunities. For example, many students wanted more interaction with the courts, legal firms and legal institutions such as the European Union institutions. However, other students considered other experiential learning techniques such as work placements, Erasmus study abroad programmes, judicial shadowing programmes and moot courts would be of benefit. Students also requested that more guest speakers be invited to the Law School to give information on legal careers and internship opportunities.

\section{Has this tour made you more willing to engage in other extra-curricular activities?}

Once again the response of students to this question was overwhelming, with $100 \%$ of students expressing a desire to become more involved in extracurricular activities. This was in stark contrast to the prior low levels of interest in volunteering to take part in moot court competitions within the school. Students reported that the field trip had provided them with a greater insight into the profile of a professional lawyer and the importance of developing their curriculum vitae beyond the academic field. While noting the importance of academic achievement, the students found that involvement in other activities such as moot court competitions was a very important aspect of the legal profession. One student commented:

\footnotetext{
Yes, I think the tour highlighted that all institutions look for students with extracurricular activities as well as high grades so it is important to take advantage of whatever extra-curricular activities we are offered in DCU. [R17]
}

\section{Conclusion}

The use of short-term experiential learning techniques, such as field trips, has long been recognised as an important tool for education in the social sciences, providing significant benefits for both students and lecturers. The use of field trips in legal education is commonplace but the benefits or assumed benefits of these trips have never been empirically measured. The objective of this article has been to analyse a limited sample of student surveys based on a legal tour that was incorporated into the first year undergraduate law curriculum. The authors are aware that the sample size is restricted. However, the results obtained are so overwhelmingly consistent that it is possible to distil a number of very important principles.

First, the use of field trips in legal education is beneficial from a number of perspectives: as a motivating tool for both study and extra-curricular activities 
and as a means of contextualising legal theory and focusing the students on career options and possibilities. One of the most significant benefits is also the de-mystification of the legal professions and the courts. After the field trip, students were much more confident in dealing with the professions and visiting the courts. One student commented that even knowing the layout of the court house and the courtroom was beneficial as it removed the sense of intimidation that had previously existed. The field trip acted as an empowering tool for students and assisted them in gaining ownership over future learning experiences.

Secondly, the trip also encouraged the development of other very important skills in the students, some associated with legal education and other more general personal skills also. The students witnessed advocacy in action in the Supreme Court and realised the importance of moot court activities in the university setting. Other skills, such as curriculum vitae development and improved confidence in dealing with legal professionals were also advanced during the field trip.

Finally, the field trip also had some unintended consequences. The students on the field trip reported that it had been a very important bonding experience with other students in their class whom they had not had an opportunity to meet and get to know during the busy law school term. Also, the students observed that their relationships with their lecturers improved during the trip and they were now more confident in approaching them for help and guidance in the future.

"Law schools serve as launching pad and gatekeeper for the legal profession". ${ }^{61}$ The results of this survey reveal that structured field trips in legal education are a valuable short-term experiential learning tool and should be strategically incorporated into the legal education curriculum. Field trips provide students with an opportunity to observe the law in action, contextualise their legal theory and develop important legal and personal skills. Confucius once wrote: "I hear and I forget. I see and I remember. I do and I understand". ${ }^{62}$ Field trips create an opportunity for students to "do" law. This research reveals that this element of "doing" does, in fact, increase a law student's "understanding" of law, legal professionals and their role as a student of law.

\footnotetext{
${ }^{61}$ Carol Silver, Amy Garver and Lindsay Watkins, "Unpacking the Apprenticeship of Professional Identity and Purpose: Insights from the Law School Survey of Student Engagement" (2011) 17, The Journal of the Legal Writing Institute, available at http://bestpracticeslegaled.files.wordpress.com/ 2011/04/carnegie-paper-silver-et-al.pdf (accessed 22 April 2012).

${ }^{62}$ Confucius, Chinese Proverbs, quoted in James W. Gentry, Jeffrey J. Stoltman and Carol E. Mehihoff, "How Should We Measure Experiential Learning?" (1992) 19 Developments in Business Simulation \& Experiential Exercises 54-57, at p. 54.
} 